\title{
Aging at Work: A Review of Recent Trends and Future Directions
}

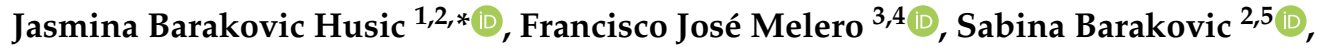

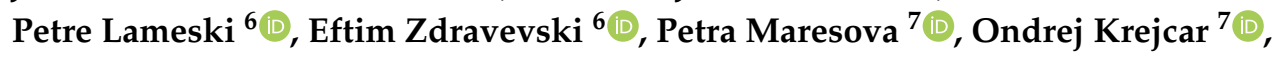 \\ Ivan Chorbev ${ }^{6}\left(\mathbb{1}\right.$, Nuno M. Garcia ${ }^{8}(\mathbb{1})$ and Vladimir Trajkovik ${ }^{6}$ \\ 1 Department of Telecommunications, Faculty of Electrical Engineering, University of Sarajevo, \\ 71000 Sarajevo, Bosnia and Herzegovina \\ 2 Little Mama Labs, Gradacacka 29, 71000 Sarajevo, Bosnia and Herzegovina; barakovic.sabina@gmail.com \\ 3 Technological Centre of Furniture and Wood of the Region of Murcia (CETEM), C/Perales S/N, \\ 30510 Yecla, Spain; fj.melero@cetem.es \\ 4 Telecommunication Networks Engineering Group, Technical University of Cartagena, \\ 30202 Cartagena, Spain \\ 5 Faculty of Transport and Communications, University of Sarajevo, 71000 Sarajevo, Bosnia and Herzegovina \\ 6 Faculty of Computer Science and Engineering, Ss Cyril and Methodius University in Skopje, \\ 1000 Skopje, North Macedonia; petre.lameski@finki.ukim.mk (P.L.); eftim.zdravevski@finki.ukim.mk (E.Z.); \\ ivan.chorbev@finki.ukim.mk (I.C.); vladimir.trajkovik@finki.ukim.mk (V.T.) \\ 7 Faculty of Informatics and Management, University of Hradec Kralove, \\ 50003 Hradec Kralove, Czech Republic; petra.maresova@uhk.cz (P.M.); ondrej.krejcar@uhk.cz (O.K.) \\ 8 Instituto de Telecomunicações, Universidade da Beira Interior, 6201-001 Covilhã, Portugal; ngarcia@di.ubi.pt \\ * Correspondence: jbarakovic@etf.unsa.ba
}

Received: 14 September 2020; Accepted: 14 October 2020; Published: 20 October 2020

\begin{abstract}
Demographic data suggest a rapid aging trend in the active workforce. The concept of aging at work comes from the urgent requirement to help the aging workforce of the contemporary industries to maintain productivity while achieving a work and private life balance. While there is plenty of research focusing on the aging population, current research activities on policies covering the concept of aging at work are limited and conceptually different. This paper aims to review publications on aging at work, which could lead to the creation of a framework that targets governmental decision-makers, the non-governmental sector, the private sector, and all of those who are responsible for the formulation of policies on aging at work. In August 2019 we searched for peer-reviewed articles in English that were indexed in PubMed, IEEE Xplore, and Springer and published between 2008 and 2019. The keywords included the following phrases: "successful aging at work", "active aging at work", "healthy aging at work", "productive aging at work", and "older adults at work". A total of 47,330 publications were found through database searching, and 25,187 publications were screened. Afterwards, 7756 screened publications were excluded from the further analysis, and a total of 17,431 article abstracts were evaluated for inclusion. Finally, further qualitative analysis included 1375 articles, of which about 24 are discussed in this article. The most prominent works suggest policies that encourage life-long learning, and a workforce that comprises both younger and older workers, as well as gradual retirement.
\end{abstract}

Keywords: aging at work; discrimination; growth; deficit; assistance; policy; legislation

\section{Introduction}

The older population is growing rapidly. In 2019, approximately 700 million people were aged 65 years or more in the world population. It is anticipated that this number will be doubled to 1.5 billion 
in 2050 [1]. During the next three decades, the size of the aging population in the European Union (EU) will have the same rising trend resulting in 149 million people in 2050 [2].

The growth of the older population is an effect of a reduced fertility rate and an increased life span [3]. Various factors influence the population aging, such as improved conditions in life and work, healthy lifestyles, and enhanced healthcare [4]. They lead to the growth of the aging population, which in turn, poses a broad range of economic challenges, including labour supply reduction and higher social costs. The aging population will continue to grow leading to a labor force reduction. This will lead to changes in the retirement age, an increased burden on government finances, and lower levels of pension provision [5].

Societies need to take a smart and multidimensional view of aging since these individuals may provide vast economic and social opportunities [6]. Rather than disrupting economic and social growth, the aging population may instead stimulate the social transformation of the 21st century, which can affect all sectors of society, including labour markets, the need for goods and services, as well as family structures and connections that affect several generations [2]. This process is focused on the transformation of the labour market by recognizing the aging population and its needs and capabilities. Older workers cannot perform certain jobs as a result of physical changes that progress with age [7]. Therefore, it is necessary to assess their current capabilities, modify their work positions, or employ them in a different position after appropriate training [8].

Not employing older people in certain work positions does not have to be a symptom of age-based discrimination, which is the most common form of discrimination, with one in five workers having witnessed it or personally experienced it [9]. It comes from a negative image of aging, preconceptions, and the overall perceptiveness of older workers themselves [10]. For example, there are stereotypes regarding the gender [11] or productivity of older people [12,13], the correlation between old age and illness [14], etc. Those stereotypes are sufficient motivation to look for a potential solution in policies and legislation that aim to inhibit discrimination, as well as promote an affirmative image of the aging labour force.

Sustainable growth at work means reaching the living and working conditions that support older people in their involvement in and continuance of work for a longer duration in their lifetime [15]. To achieve this, work has to be transformed to eliminate the factors that demotivate older workers to stay in or enter the labor market $[16,17]$. Concerns about the work sustainability, including the economic growth, pensions, and labour supply, have motivated a policy response as a potential solution to address the issues of longer working lives and later retirement $[18,19]$.

Furthermore, an employment deficit calls for an effective response that should balance economic and regulatory needs with an influence on the jobs, working conditions, skills demands, and social protection [20]. Despite the many measures to cope with this issue [21,22], such as the unemployment benefits, social protection, and public employment services, activation of new policies is required as a potential solution to facilitate transitions to new jobs and decrease the risk of long-term unemployment and inactivity. Policies and legislation that encourage life-long learning seem to be an effective solution for preparing employees to change jobs if they cannot continue their current work due to decreasing opportunities [23].

In response to the aforementioned issues, the aging labour force has been studied over the last decade to contribute to the understanding of different motivations and solutions in the given context. However, there is a lack of systematic review of these motivations and solutions to support the aging labour force. Therefore, the aim of this paper is twofold. The first goal is to recognize and summarize the articles related to the aging labour force in terms of recent trends and future directions. The second objective is to capture the main motivation issues and solutions to support the concept of aging at work, i.e., the aging labour force.

The following research questions were posed:

1. What are the motivations that drive the research on the aging labour force?

2. What are the most common solutions for addressing the issues related to aging at work? 


\section{Methodology}

\subsection{Article Search Strategy}

In order to answer the research questions, we examined studies on the aging labour force that were published between January 2008 and August 2019, to recognize the trends in the literature written in English with respect to motivation issues and potential solutions. We focused on the trends starting from the recession in 2008, when, although the economic growth slowed, the employment rate of older people remained strong, thus basically changing the position of older workers [24]. An additional motivation for focusing on this time period was because in the last decade, many assistive technologies have emerged that can aid older adults in different environments. At the same time, many jobs are transforming and can be successfully performed from home, which has recently become evident with the COVID-19 pandemic. Considering these two observations, the goal of this research is to investigate whether there is an underlying trend that reveals opportunities for aging at work.

We adopted the Preferred Reporting Items for Systematic Review and Meta-Analysis (PRISMA) methodology [25] to review the literature on aging at work policies. The PRISMA flow distinguishes separate stages of systematic reviews. These stages are the collection of papers, scanning of papers' text, evaluation of eligibility of papers, and meta-analysis.

The collected papers on aging at work policies exceeded the capacity that would allow articles to be searched manually. Thus, we used natural language processing (NLP) algorithms to perform an efficient search of the identified literature. The NLP toolkit [26] was designed to automate the literature search by using different search phrases, scanning, and evaluating eligibility within the PRISMA framework while generating visualizations of aggregate results. The NLP toolkit provides increased efficiency of the review process by screening the title and abstract while using the predetermined properties and their synonyms to determine the literature search phrases. It should be noted that the NLP toolkit does not understand the context and, therefore, categorizes more articles as relevant than a human reader would. However, it is a valuable resource that increases the efficiency of the review process, as demonstrated in a scoping review [27] that focused on wearable technology for connected health. The adopted PRISMA information flow is shown in Figure 1. Since the NLP toolkit automates the review process of publications that are indexed in only three digital libraries and because we have not taken into account the nonindexed publishers, some relevant publications (e.g., reference [28]) have been omitted from the analysis. This one and a few other papers were manually identified, and those publications originated from different digital libraries. They were used to confirm the findings of this review. However, we did not use these papers from other digital libraries to identify trends because the size of the searched digital libraries is sufficient for the purpose of the analysis.

The NLP search strategy was applied in order to automatically screen irrelevant articles that have a low correlation with the topics of interest in the study. Additionally, it helped in consolidating the collected articles by automatically merging results from multiple digital libraries as well as removing duplicate entries. Moreover, it allowed us to iteratively fine-tune and modify the search phrases in the hope of identifying more relevant articles. Finally, the NLP toolkit automatically generated charts (such as Figures 2-5) that highlight the trends of publications for certain topics. For more details about the inner workings of the NLP-based toolkit, we refer interested readers to [26], and also to [27], which applied it to review wearable technology for connected health.

By using yearly graphs, we were able to analyze and report the potential trends in data by investigating articles in each property group (i.e., theme) separately.

The NLP toolkit input parameters are a collection of phrases. Keywords, together with their synonyms, are applied as search terms for the digital libraries used in the literature search. The input can be further expanded by NLP toolkit properties. Properties are phrases that are being searched within the title, abstract, or keywords section of the articles identified from the previous keywords search. Property groups are sets of properties that can be used for a more comprehensive presentation of search results. 


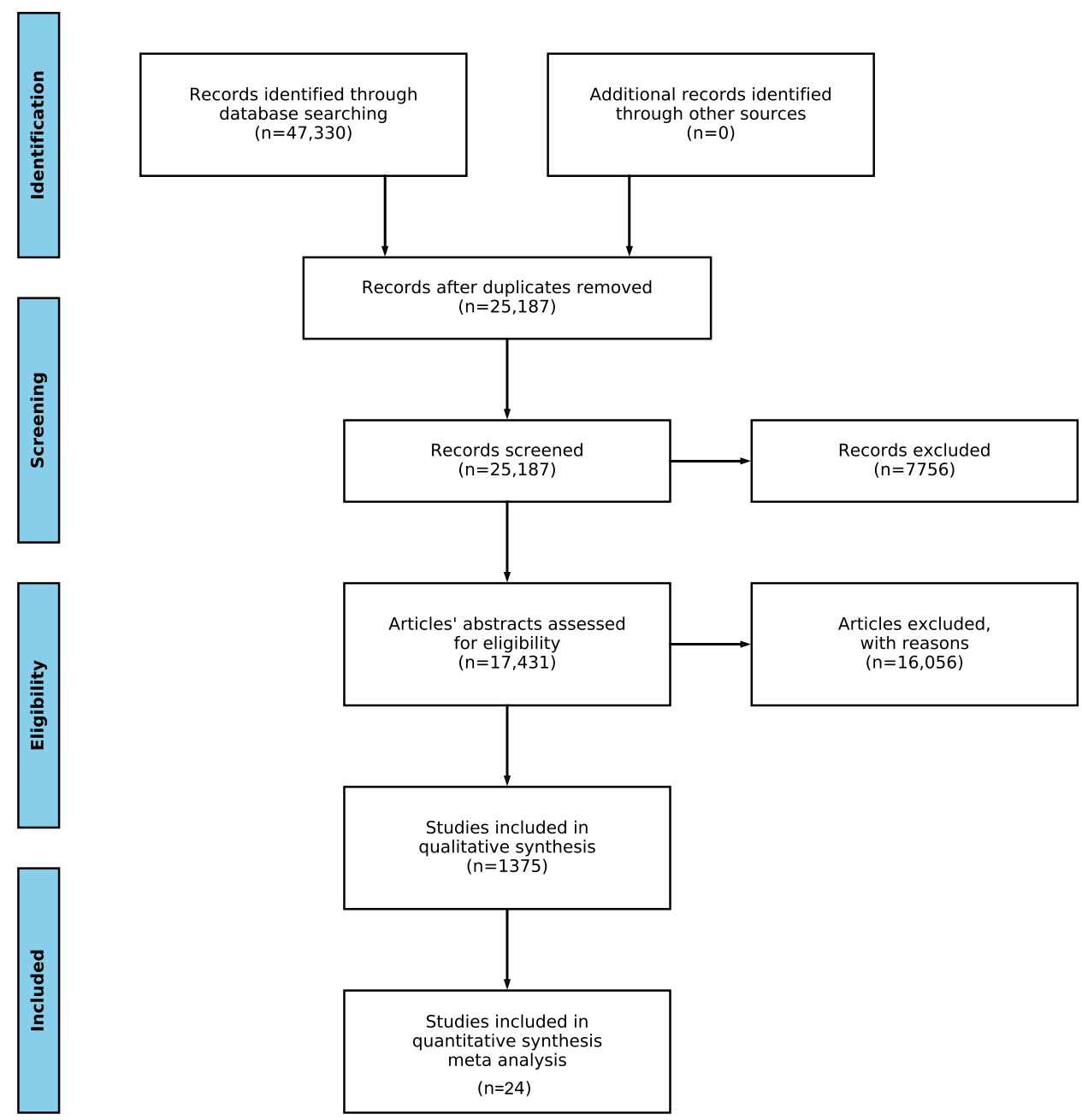

Figure 1. The PRISMA review workflow reflecting the number of articles identified, screened, processed and removed in each step.

The input parameters used in this study are shown in Table 1. These keywords, property groups and properties are the final versions after an iterative process in which all authors participated and considered different alternatives of keywords and properties, and analyzed the preliminary results. In the process of selecting articles to be included in the quantitative synthesis, four authors participated, of which at least two had to be in agreement.

Table 1. The NLP toolkit input parameters: keywords, property groups and properties.

\begin{tabular}{ll}
\hline Keywords & $\begin{array}{l}\text { "active aging at work", "older adults at work", "successful aging at work", } \\
\text { "healthy aging at work", "productive aging at work" }\end{array}$ \\
\hline Property Groups & Properties \\
\hline Motivations & "deficit", "discrimination", "growth" \\
\hline Solutions & $\begin{array}{l}\text { "EU policy", "assistance schemes", } \\
\text { "eligibility criteria", "legislation", "national policy" }\end{array}$ \\
\hline
\end{tabular}




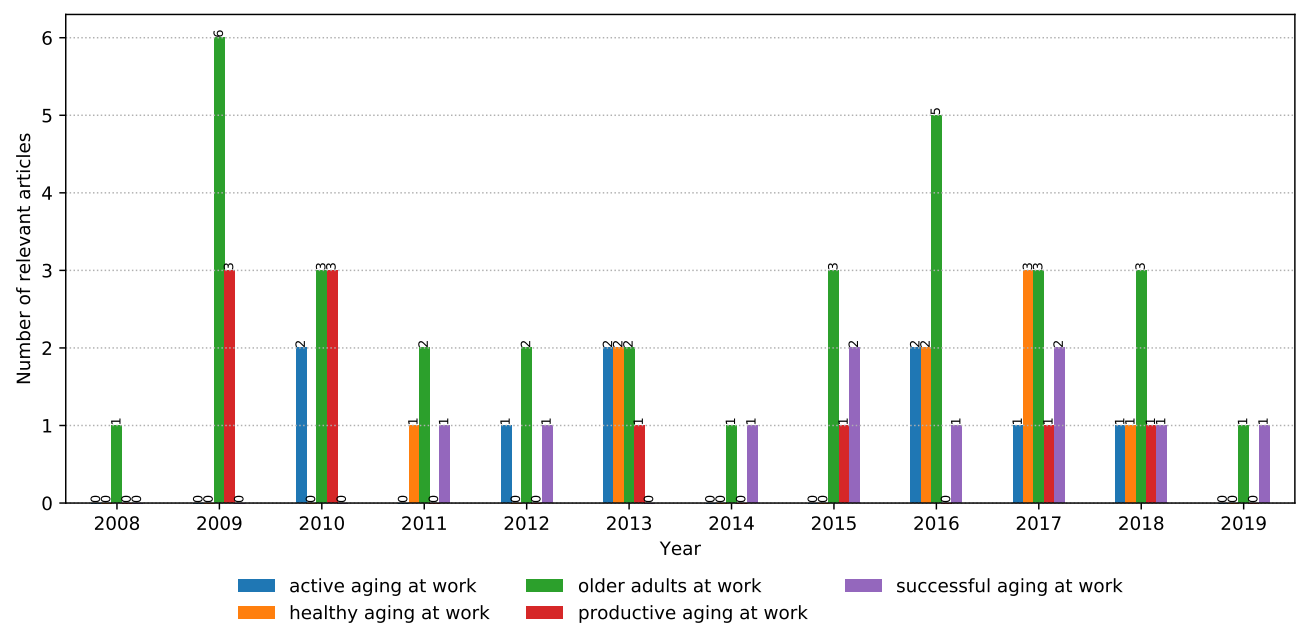

Figure 2. The number of identified relevant articles per year from January 2008 to August 2019.

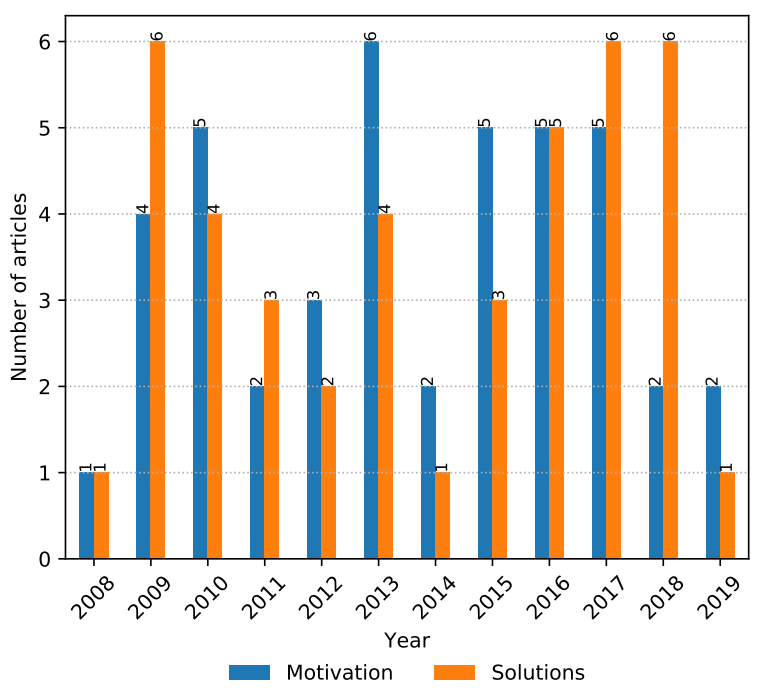

Figure 3. The number of relevant articles per property group and year within the period of interest.

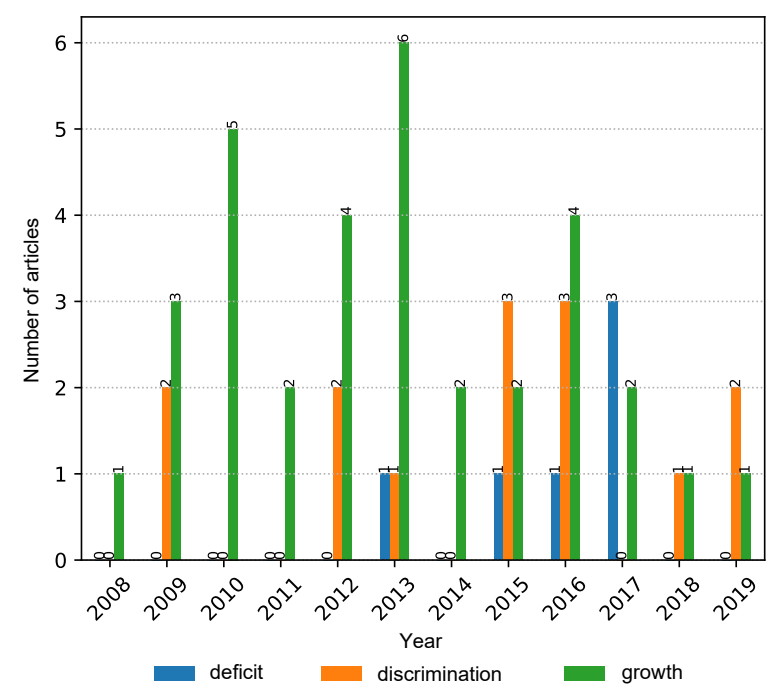

Figure 4. The number of relevant articles related to motivations property group categorized by "deficit", "discrimination", and "growth" properties from 2008 to 2019. 


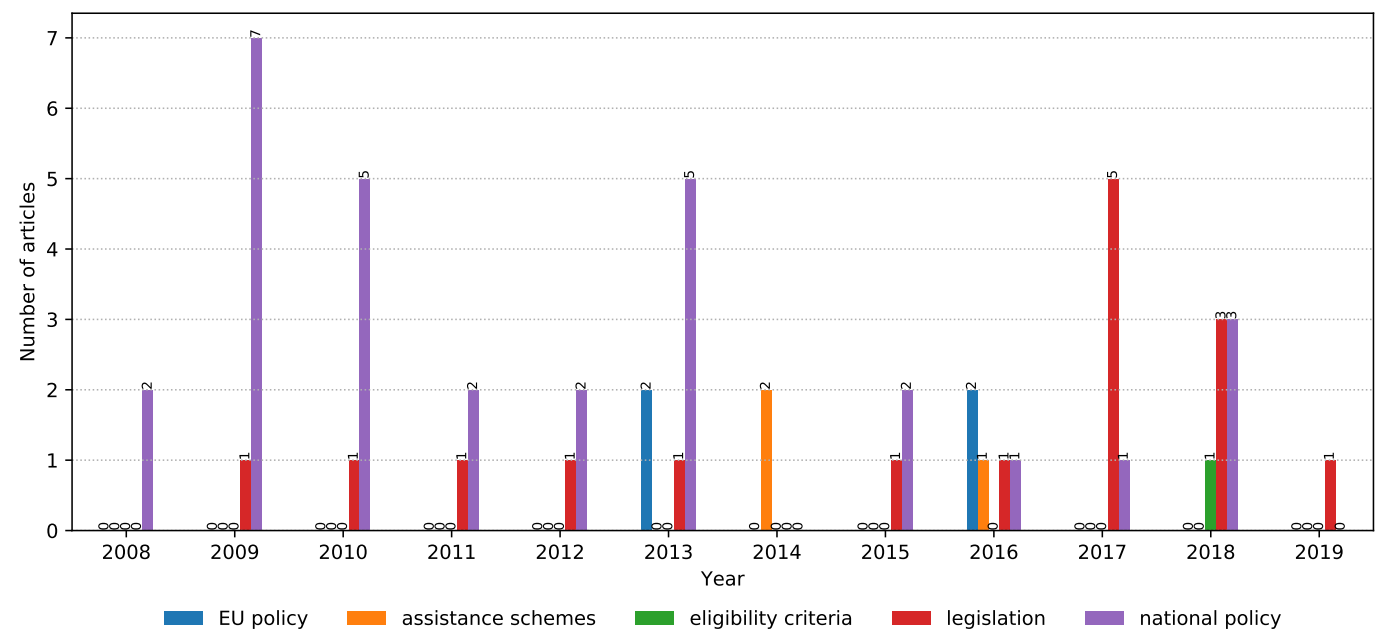

Figure 5. Solutions-related properties: "EU policy", "assistance schemes", "eligibility criteria", "legislation", and "national policy". The trends apply to the period from 2008 to 2019.

\subsection{Article Selection Process}

The titles and abstracts retrieved by the NLP-based search strategy were evaluated by two independent researchers. They compared their opinions in order to select articles that satisfied the inclusion and exclusion criteria.

The inclusion criteria were as follows:

1. Articles that consider the concept of aging at work, i.e., the aging labour force.

(a) Articles that discuss any of three motivation factors, i.e., discrimination, growth, and deficit;

(b) Articles that support any of three solution pillars, i.e., assistance, policies, and legislation.

2. Articles that use research methodology with any results.

The exclusion criteria were as follows:

1. Articles that are about aging and older people in general that do not consider the concept of aging at work;

2. Articles that cover any of three motivation factors, i.e., discrimination, growth, and deficit, in a context other than the aging labour force;

3. Articles that cover any of three solution pillars, i.e., assistance, policies, and legislation, in the context other than the aging labour force;

4. Articles that do not provide sufficient information for classification.

When researchers differed in their opinions about an article's suitability, the article was selected for further consideration. This resulted in an initial selection of 70 articles. Furthermore, the full texts of the chosen articles were reviewed in order to determine their suitability for further discussion. After the data abstraction of the final selected articles, two additional researchers separately reviewed $20 \%$ of randomly chosen articles. In the case of any disagreement on the suitability of articles, a third researcher was consulted for recommendation and assessment of the given article. This researcher was a specialist who drew a final conclusion regarding the article selection process.

For the selection of the final 24 articles, two of three authors needed to be in agreement, considering the completeness of the methods, relevance to the study goal, details about the population, and impact of the study. 


\subsection{Article Review and Analysis}

We used the inductive approach for the article review and analysis. The selected articles were systematically organized into two groups:

1. Articles that focused on motivation factors (i.e., discrimination, growth, and deficit);

2. Articles that focused on solution pillars (i.e., assistance, policies, and legislation).

We generated a detailed summary of each article and extracted the following items: objective, methods, main findings, limitations, and keywords. The extracted items provided the input data for discussion and conclusions.

\section{Results}

After searching PubMed, IEEE Xplore, and Springer, we identified 47,330 potentially articles. After performing the PRISMA steps shown in Figure 1, the number of articles was reduced. Specifically, the removal of duplicates reduced the number to 25,187 studies. The first screening process eliminated an additional 7756 studies with an out-of-scope publication year, or other parsing issues (no title, abstract, etc.). Then, 17,431 papers were subject to the eligibility estimate using the automated NLP toolkit, which removed articles without any of the required properties. Eventually, 1375 papers remained as potentially relevant and eligible for further manual inspection. A total of 70 articles were initially selected to analyze the trends on the aging labour force, while 24 articles were used to explore the motivation issues and solutions in the given context.

\subsection{Trends}

The selected keywords aimed to show different aspects on the literature corpus on aging at work. Figure 2 presents the number of potentially relevant papers that contained the defined keywords and that were additionally filtered manually based on their relevance to the defined properties per year. A relatively similar number of identified articles can be observed in the evaluated time period. "Active aging at work" is the keyword with the smallest number of occurrences. The most frequent keyword phrase in the identified publications is "older adults at work". The number of research articles did not grow in the period of interest, but articles that address the associated keywords seem to be distributed more evenly over time.

Findings related to property groups show that the number of papers related to "motivation" of the adult workforce is relatively constant, with a small decline in the last two years, while the papers focused on the "solutions" property group seems to be slightly more predominant in the last few years (Figure 3).

A more granular analysis was carried out on the property groups data at the properties level, and the chart reveals that "growth" is the primary topic within the motivation group of papers, followed by "discrimination". The papers related to the topic of "deficit" appeared only in recent years (Figure 4).

The focus of papers within the "solutions" property group (Figure 5) seems to move from "national policy" based to "legislation", while "assistant schemes" and "EU policies" seem to be of smaller interest for the scientific community. There was only one paper that addressed "eligibility criteria", which makes this topic interesting for further research.

\subsection{Motivations}

A total of 12 articles out of 24 were selected for the further analysis of motivations that drive the research on the aging labour force. The selected articles were organized into three focus groups according to the considered terms related to motivation, i.e., "discrimination", "growth", and "deficit". A more detailed analysis of these articles is presented in Table 2. 


\subsection{Solutions}

The remaining 12 articles out of 24 were used for a more detailed analysis of solutions for the aging labour force. The selected articles were organized into three focus groups according to the considered solutions, i.e., assistance, policy, and legislation. Table 3 shows results of the analysis.

\section{Discussion}

\subsection{Study Implications and Recommendations}

The ageing labour force could represent a risk both for society and economy unless it is well managed. Therefore, the attention that researchers, governments and other stakeholders have devoted to this issue has grown over the time. According to analysis of motivations (Table 2) and solutions (Table 3) for ageing at work, possible policy implications have been identified and split into five parts:

Extend the length of work ability. Different organizations implement changes by creating common policies and strategies, but they are not oriented toward the older workforce. Intentionally interrupting the existing age-graded logic and its replacement with age-neutral logic are proposed in [16]. The authors in [29] found that the expected decline in employment could be partially offset by public policies that encourage the employment of older people. This causes problems for public finances due to expenditures on health, long-term care, pensions, etc. [3]. In order to encourage policies to maintain work ability at an old age, it is necessary to invest in decreasing of both work stress and social inequalities in health care [30]. However, extending the length of work ability does not just pose issues, but provides social and economic opportunities.

Avoid the age-based discrimination. The labour market will have to adapt working positions and eliminate the attitude of age-based discrimination, since it will have to fight for a working force older than 65 because it is lacking. When facing age-based discrimination at work, the organizational help and friends and family support were found to be significant in achieving better health and adaptability [31]. On the other hand, older workers with high job satisfaction without age-based discrimination remained longer in the labour market [32]. Finally, the authors in [10] found that experiences of discrimination were rare and reduced with age among men, whereas almost no age differences were noticed among women. This indicates that age-based discrimination is possibly overstated, and age-related obstacles could have been miscomprehended. Therefore, the flexibility of older workers can be seen as an opportunity for the active global aging trend [33]. 
Table 2. Detailed analysis of articles that focus on motivation factors.

\begin{tabular}{|c|c|c|c|c|c|c|}
\hline Focus & Study & Objective & Methods & Main Findings & Limitations & Key Words \\
\hline \multirow{4}{*}{ 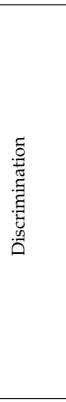 } & [32] & $\begin{array}{l}\text { To recognize psychosocial work condition factors } \\
\text { of interest to keep older workers by assessing the } \\
\text { connection between the psychosocial work conditions } \\
\text { and early voluntary pension. }\end{array}$ & 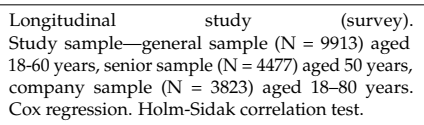 & $\begin{array}{l}\text { Older workers with high job satisfaction, development possibilities, } \\
\text { affirmative relations to managagement, and no age discrimination } \\
\text { stayed longer in the work market Positive relations with colleagues } \\
\text { did not affect older workers decisions on early pension. }\end{array}$ & $\begin{array}{l}\text { The measures were self-evaluated. The psychosocial factors } \\
\text { were measured at single time point. Successive changes in } \\
\text { the psychosocial work conditions could cause early pension } \\
\text { that would be missed by the study. }\end{array}$ & $\begin{array}{l}\begin{array}{l}\text { Early pension, work conditions, } \\
\text { management } \\
\text { job satisfaction quality, }\end{array} \\
\end{array}$ \\
\hline & [31] & $\begin{array}{l}\text { To examine the relation between successful aging and } \\
\text { stress sources at work among older workers in China }\end{array}$ & $\begin{array}{l}\text { Questionnaire study. } \quad \text { Study sample }-242 \\
\text { workers aged }>40 \text { years. Method variance. } \\
\text { Harman's one-factor test. Factor analysis. }\end{array}$ & $\begin{array}{l}\text { Perception of institutional support and social help from family and } \\
\text { friends significantly corresponds to efficient aging at work. }\end{array}$ & $\begin{array}{l}\text { Participants were surveyed at a single time point. The study } \\
\text { relied on participants self-reports. }\end{array}$ & $\begin{array}{l}\text { Successful aging, work stressor, } \\
\text { social help, institutional support }\end{array}$ \\
\hline & [10] & $\begin{array}{l}\text { To improve comprehension of the discrimination } \\
\text { at work, with a focus on age and gender challenges. }\end{array}$ & $\begin{array}{l}\text { Survey study. Study sample- } 3203 \text { workers } \\
\text { with mean age } 43 \text { years. Computer-aided } \\
\text { telephone interview. Binary logistic regression. }\end{array}$ & $\begin{array}{l}\text { Daily discrimination was unusual. It appears with age among men, } \\
\text { and not among women. The nature of work market age obstacles } \\
\text { is not understood correctly, and the degree of aging discrimination } \\
\text { is overstated. }\end{array}$ & $\begin{array}{l}\text { There was a small number of workers who faced daily } \\
\text { discrimination. The degree of daily discrimination has to be } \\
\text { further investigated. }\end{array}$ & $\begin{array}{l}\text { Ageism, } \begin{array}{l}\text { employment } \\
\text { discrimination, gender, work }\end{array} \\
\text { d w }\end{array}$ \\
\hline & [33] & $\begin{array}{l}\text { To investigate the age-related } \\
\text { connection } \\
\text { between job stress, extreme tiredness, } \\
\text { prosperity, and associated personal, institutional, } \\
\text { and community factors. }\end{array}$ & $\begin{array}{l}\text { Survey study. Study sample- } 1298 \text { participants } \\
\text { aged } 18 \text { years or older. Descriptive statistics. } \\
\text { Linear Regression. One-way analysis of variance. }\end{array}$ & $\begin{array}{l}\text { Job stress was associated with several types of extreme tiredness } \\
\text { and prosperity. Personal work styly, institutional and community } \\
\text { factors were associted with prosperity. Old age was connected to a } \\
\text { poor perception of health. }\end{array}$ & $\begin{array}{l}\text { The study did not compare work differences. The data were } \\
\text { cross-sectional and the causas relation of the work conditions } \\
\text { and style with job stress, extreme tiredness, and prosperity } \\
\text { could not be confirmed. }\end{array}$ & $\begin{array}{l}\text { Age difference, exhaustion, } \\
\text { prosperity, work stress, } \\
\text { work condition }\end{array}$ \\
\hline \multirow{4}{*}{ 章 } & [30] & $\begin{array}{l}\text { To investigate the connection of social, demographic, } \\
\text { economic and job related factors with disability. }\end{array}$ & 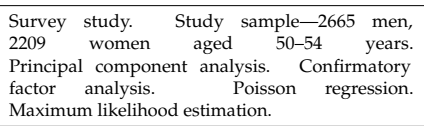 & $\begin{array}{l}\text { A decrease in job stress and sociable disproportion in healthcare } \\
\text { is appropriate for the development of policies that support aging } \\
\text { at work. }\end{array}$ & $\begin{array}{l}\text { The disability indices were not formulated based on } \\
\text { functional testing. The evaluation of stressful work was } \\
\text { performed by abbreviated scales. }\end{array}$ & $\begin{array}{l}\text { Socioeconomic position, } \\
\text { aging workforce, work stress, } \\
\text { work ability, social disproportion }\end{array}$ \\
\hline & [16] & $\begin{array}{l}\text { To examine organizational work disrupting } \\
\text { age-graded policies. }\end{array}$ & $\begin{array}{l}\text { Interview study. Study sample-23 organizations } \\
\text { with employees aged } 50-69 \text { years. Qualitative } \\
\text { content analysis. }\end{array}$ & $\begin{array}{l}\text { Organizations implement changes by creating common policies } \\
\text { and strategies, but not those oriented toward an aging workforce. } \\
\text { They propose to intentionally interrupt the existing age-graded logic } \\
\text { and replace it with age-neutral logic. }\end{array}$ & $\begin{array}{l}\text { Creative, high-tech, or communications organizations were } \\
\text { not studied. Sample size was small, so broader claims about } \\
\text { Minnesota or U.S. workers cannot be made. }\end{array}$ & $\begin{array}{lr}\begin{array}{l}\text { Organizational } \\
\text { older } \\
\text { pension, flexibility }\end{array} & \begin{array}{l}\text { logic, } \\
\text { workers, }\end{array}\end{array}$ \\
\hline & [29] & $\begin{array}{l}\text { To examine the influence of demographic trends on the } \\
\text { economic growth and employment level that Japan is } \\
\text { expected to face in the next } 20 \text { years }\end{array}$ & $\begin{array}{l}\text { NUPRI Macro Simulation model of the economy in } \\
\text { Japan }\end{array}$ & $\begin{array}{l}\text { The expected decline in employment could be partially offset by } \\
\text { public policies that encourage the employment of older people. }\end{array}$ & Not reported. & $\begin{array}{l}\text { Low fertility, population decline, } \\
\text { population aging }\end{array}$ \\
\hline & [3] & $\begin{array}{l}\text { To provide a literature review on the need for the senior } \\
\text { workforce and recognize main directions for research } \\
\text { on this topic. }\end{array}$ & Systematic literature review. Empirical evidence. & $\begin{array}{l}\text { There is a negative association between salary and employment } \\
\text { outcomes for the senior workforce. The connection between } \\
\text { efficiency and salary is defined by governmental conditions and } \\
\text { motivation to take early pension. }\end{array}$ & $\begin{array}{l}\text { The variations in micro-, macro-, and meso-level factors } \\
\text { were not captured, simultanoeucly. There is a need for } \\
\text { imprrovements in the analysis of the impact of gae-based } \\
\text { discrimination on the employing of older workers. }\end{array}$ & $\begin{array}{l}\text { Work market, employment } \\
\text { protection, regulation, legislation }\end{array}$ \\
\hline \multirow{4}{*}{$\begin{array}{l}\text { 营 } \\
\text { 音 }\end{array}$} & [17] & $\begin{array}{l}\text { To examine the influence of organizational factors on } \\
\text { work ability. }\end{array}$ & $\begin{array}{l}\text { Cross-sectional study (online survey). Study } \\
\text { sample- } 306 \text { employees. Path analysis modeling. } \\
\text { Maximum likelihood estimation. }\end{array}$ & $\begin{array}{l}\text { Organizational culture and professional effort indirectly enabled } \\
\text { the prediction of work ability, with job satisfaction mediating these } \\
\text { relations. }\end{array}$ & $\begin{array}{l}\text { The sample included mostly younger and female workers. } \\
\text { The cross-sectional design of the study did not provide } \\
\text { the possibility to understand causes and effects related to } \\
\text { work ability. }\end{array}$ & $\begin{array}{l}\text { Work } \\
\text { organizational culture }\end{array}$ \\
\hline & [34] & $\begin{array}{l}\text { To recognize professions prevailed by an older } \\
\text { workforce and evaluate their vulnerability to hazards } \\
\text { in these professions. }\end{array}$ & $\begin{array}{l}\text { Survey study (interviews). Study sample- } 6502 \\
\text { workers aged } 55 \text { or more. Chi-squared test. }\end{array}$ & $\begin{array}{l}\text { Work-related hazards should be decreased to inhibit professional } \\
\text { disturbance in professions prevailed by an older workforce. }\end{array}$ & Self-informed data were included in the study. & 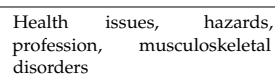 \\
\hline & [35] & $\begin{array}{l}\text { To investigate job discrimination related to age } \\
\text { and disability. }\end{array}$ & $\begin{array}{l}\text { Equal Employment Opportunity Commission } \\
\text { Integrated Mission System data from } 1993 \text { to } 2007 . \\
\text { Descriptive statistics. }\end{array}$ & $\begin{array}{l}\text { Job discrimination of aged or disabled workers is focused on } \\
\text { challenges involving seating, revenge, and cancellation. }\end{array}$ & $\begin{array}{l}\text { Data do not contain supplemental information regarding a } \\
\text { secondary cause for each filed allegation. }\end{array}$ & Job/age/disability discrimination \\
\hline & [36] & $\begin{array}{l}\text { To investigate the relation between psychosocial } \\
\text { factors and pension intention of older employees, } \\
\text { while considering healthiness and work ability. }\end{array}$ & $\begin{array}{l}\text { Survey study. Study sample }-3122 \text { workers aged } \\
50 \text { years or older. Searson correlation. Ordinal } \\
\text { logistic regression. }\end{array}$ & $\begin{array}{l}\text { Ageism and the absence of acknowledgement and growth } \\
\text { opportunities are connected to older male workers' pension } \\
\text { intention. Work ability is strongly related to the pension intention } \\
\text { of both genders. }\end{array}$ & $\begin{array}{l}\text { The pension age could depend on unfamiliar alternations in } \\
\text { the worker's environment or health status. }\end{array}$ & $\begin{array}{l}\text { Psychosocial factors, pension } \\
\text { intention, } \\
\text { work ability } \quad \text { healthiness, }\end{array}$ \\
\hline
\end{tabular}


Table 3. Detailed analysis of articles that focus on solutions.

\begin{tabular}{|c|c|c|c|c|c|c|}
\hline Focus & Study & $\begin{array}{l}\text { Objective } \\
\end{array}$ & Methods & Main Findings & Limitations & Key Words \\
\hline \multirow{3}{*}{ 要 } & [37] & $\begin{array}{l}\text { To critically review the literature on older farmers } \\
\text { in Canada and the USA and describe how } \\
\text { musuculoskeletal disorders influence their ability } \\
\text { to work. }\end{array}$ & $\begin{array}{l}\text { Literature review. Twelve articles analyzed } \\
\text { in detail. }\end{array}$ & $\begin{array}{l}\text { Musculoskeletal disturbance can lead to trauma or loss of ability to farm. } \\
\text { It in seecesart to develop safer work practices and encourage healthiness, } \\
\text { efficicency, and professional longevity. }\end{array}$ & $\begin{array}{l}\text { Some related articles may have been excluded from the study due } \\
\text { to the specificity of the search strings. }\end{array}$ & $\begin{array}{l}\text { Older farmers, work-related } \\
\text { musculoskeletal disorders, pension age }\end{array}$ \\
\hline & [8] & $\begin{array}{l}\text { To investigate the action plans that workers use to } \\
\text { acquire skills in software and complete assignments }\end{array}$ & 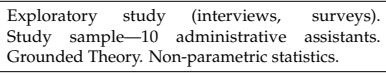 & $\begin{array}{l}\text { Administrative assistants are regularly communicating and } \\
\text { sharing knowledge. }\end{array}$ & $\begin{array}{l}\text { Exclusion of workers from different organizations, lack of extensive } \\
\text { investigation on behavior at work, and creation of software tool } \\
\text { design instructions. }\end{array}$ & Workplace, generations, collaboration \\
\hline & 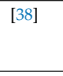 & $\begin{array}{l}\text { To collect information to direct the preparation of } \\
\text { programs for returning older adults to work }\end{array}$ & $\begin{array}{l}\text { Survey study (questionnaires). Study sample-37 } \\
\text { jobless participants aged 51-76 years. ANOVA. } \\
\text { Chi-square test. }\end{array}$ & $\begin{array}{l}\text { Participants who felt discriminated indicated the preference to acquire } \\
\text { technological skills and ge classroom-based education. }\end{array}$ & Work obstacles could not be generalized. & $\begin{array}{l}\text { Older } \begin{array}{l}\text { workers, } \\
\text { technologicance } \\
\text { teckllls, } \\
\text { work experiences conditions, }\end{array} \\
\end{array}$ \\
\hline \multirow{5}{*}{ 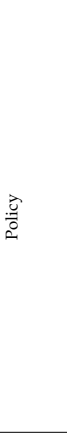 } & [39] & $\begin{array}{l}\text { To investigate factors related to perceived work ability } \\
\text { in a sample of Brazilians sample aged } 50 \text { years } \\
\text { and more }\end{array}$ & $\begin{array}{l}\text { Longitudinal study } \quad \text { (surveys). } \\
\text { sample } 8900 \text { w workers aged 50 years and } \\
\text { saltivariate } \\
\text { Multivariate analysis. Poisson regression. }\end{array}$ & $\begin{array}{l}\text { Work ability in old age depends on the life course, i.e., academic level, } \\
\text { health conditions in younger and older age, minimum working age, ete. } \\
\text { Policies aimining to extend longevity in the work market must consider } \\
\text { these factors. }\end{array}$ & $\begin{array}{l}\text { The collection of self-reported data associated with past experiences } \\
\text { might have been affected by the preference to demonstrate an } \\
\text { acceptable image, causing information bias. Establishment of } \\
\text { temporal relatitions for the variable related to current condititions } \\
\text { is limited. }\end{array}$ & $\begin{array}{l}\text { Work } \\
\text { socioeconomic factors }\end{array}$ \\
\hline & [40] & $\begin{array}{l}\text { To review the documentation about the influence of } \\
\text { psychological health on staying at work anter pension } \\
\text { and discuss consequences of public health policies. }\end{array}$ & $\begin{array}{l}\text { Systematic literature review. Ten articles analyzed } \\
\text { in detail. }\end{array}$ & $\begin{array}{l}\text { Staying at work after pension can be positive for psychological health. } \\
\text { Pension action plans are required to provide national policies that will } \\
\text { increase the pension age and not exacerbate any disproportion in the } \\
\text { older population. }\end{array}$ & $\begin{array}{l}\text { Only cross--sectional and longitudinal studies investigating the } \\
\text { impact of unexpected variables on psychological health were } \\
\text { involved in the review. }\end{array}$ & $\begin{array}{l}\text { Pension, job status, psychological health, } \\
\text { social policy }\end{array}$ \\
\hline & [7] & $\begin{array}{l}\text { To analyze the literature on workplace health } \\
\text { promotion (WHP) aimed at older workers }\end{array}$ & $\begin{array}{l}\text { Systematic literature review. Eighteen articles } \\
\text { analyzed in detail. }\end{array}$ & $\begin{array}{l}\text { Existing documentation does not demonstrate that WHP enhance } \\
\text { work abilily, retention, efficiency, lifestyle, health, or prosperity of the } \\
\text { senior workforce. }\end{array}$ & $\begin{array}{l}\text { The heterogeneity and lo } \\
\text { to synthesize the literatur }\end{array}$ & $\begin{array}{l}\text { Workplace health promotion, senior } \\
\text { workforce, health, lifestyle }\end{array}$ \\
\hline & [41] & $\begin{array}{l}\text { To investigate the results of unfullilled expectations of } \\
\text { staying at work after age } 22 \text { on life satisfaction. }\end{array}$ & $\begin{array}{l}\text { Longitudinal survey. Study sample-1684 } \\
\text { workers aged } 51 \text { and over. Growth mixture } \\
\text { modeling. Descripive statistic. Linear regression. } \\
\text { Multi-nominal logistic regression. }\end{array}$ & $\begin{array}{l}\text { Majority of men and almost no women expected to stay at work after age } 62 \text {. } \\
\text { The subjective prosperity of older adults is affected by unmet expectations } \\
\text { of staying longer at work. }\end{array}$ & $\begin{array}{l}\text { The significance of } \\
\text { not assessed. }\end{array}$ & $\begin{array}{l}\text { Work expectations, pension, life } \\
\text { satisfaction, subjective prosperity }\end{array}$ \\
\hline & [42] & $\begin{array}{l}\text { To find out whether the workers' ages determine the } \\
\text { evaluation of their work-life balance. }\end{array}$ & $\begin{array}{l}\text { Survey study. Study sample }-500 \text { workers } \\
\text { aged from } 21 \text { to } 70 \text { years. Kruskal-Wallis test. } \\
\text { Spearman's R correlation analysis. }\end{array}$ & $\begin{array}{l}\text { The maintenance of work-life balance will be indicated by older workers. } \\
\text { All employeses do on thave the same possibilities to take advantage of } \\
\text { solutions that provide the support of work-life balance. }\end{array}$ & $\begin{array}{l}\text { The diversity of the answers given by the particip } \\
\text { the type and state of particpants affiliation was no }\end{array}$ & $\begin{array}{l}\text { Work-life balance, workers'assessment, } \\
\text { aging workforce }\end{array}$ \\
\hline \multirow{4}{*}{$\Xi^{50}$} & [13] & $\begin{array}{l}\text { To estimate the impact on the efficiency of the reduction } \\
\text { of assortment mechanisms among senior employees. }\end{array}$ & $\begin{array}{l}\text { Italian National Institute of Statistics data from } \\
2009 \text { to } 2011 \text {. Descriptive statistics. Multivariate } \\
\text { regression analysis. }\end{array}$ & $\begin{array}{l}\text { The growth of pension age, as well as limitations on early pension } \\
\text { intention, kept older workers at the work without a positive influence } \\
\text { on fefticiency More efficient odder enployees are mroe likely to stay at work } \\
\text { in comparison with those who are not as efficient. }\end{array}$ & $\begin{array}{l}\text { The number of employees kept at the work was underestimated. } \\
\text { The reform's influence on the employees' structure is an } \\
\text { additional issue. }\end{array}$ & $\begin{array}{l}\text { aging workforce, pension reforms, } \\
\text { labor productivity }\end{array}$ \\
\hline & {$[43]$} & $\begin{array}{l}\text { To investigate the workforce participation and absence } \\
\text { among older adults in Sweden. }\end{array}$ & $\begin{array}{l}\text { Data from the Swedish population register. } \\
\text { Study sample-workers aged } 55-64 \text { years. } \\
\text { Descriptive statistics. }\end{array}$ & $\begin{array}{l}\text { The alternation in regulations affected the share of workers associated } \\
\text { withtilnness and disability pension programs. Simultaneouly, the share of } \\
\text { workers going to aarly pension has growwn. }\end{array}$ & $\begin{array}{l}\text { This study noticed no alternation related to the difference in } \\
\text { working-lifif exit patterns associated with hierarchical and academic } \\
\text { positions in the organization. }\end{array}$ & $\begin{array}{l}\text { Workforce participation, older worker, } \\
\text { pension, illness benefits }\end{array}$ \\
\hline & [20] & $\begin{array}{l}\text { To review the expert way of thinking in relation to } \\
\text { policies influencing the employment of older adults. }\end{array}$ & $\begin{array}{l}\text { Survey study. Study sample- } 89 \text { participants aged } \\
50 \text { years or older. Descriptive statistics. }\end{array}$ & A broad range of policies recommend possibilities for innovation. & $\begin{array}{l}\text { There is a sampling bias related to the language and review method. } \\
\text { hhere were no participants from South America, whhile a few } \\
\text { participants from Africa demonstrated about limited Internet access. }\end{array}$ & $\begin{array}{l}\text { Aging workforce, older workers, } \\
\text { employment policy, mandatory pension, } \\
\text { government answers }\end{array}$ \\
\hline & [44] & $\begin{array}{l}\text { To investigate whetenher age and mental capabilities } \\
\text { mitigate the connection between job stress and } \\
\text { negative affect }\end{array}$ & $\begin{array}{l}\text { Survey study. Study sample- } 193 \text { workers aged } \\
25-6 \text { years. Descriptive statistics. Correlation and } \\
\text { regression analysis. Johnson-Neyman technique. }\end{array}$ & 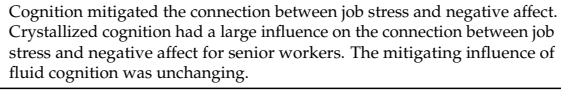 & $\begin{array}{l}\text { The etsudy did not permit a setup of directionality among variables. } \\
\text { Better evaluation of professional features and job requirements } \\
\text { is needed. }\end{array}$ & Job stress, negative affect, older workers \\
\hline
\end{tabular}


Improve the well-being of older workers. Difficulties that older people experience at work indicates a need for healthcare strategies to adjust the work conditions so that they are suitable for older workforce with decreased physical ability. The authors in [34] identified professions that are dominated by older workers and suggested that work-related hazards (e.g., noise, vibrations, etc.) should be reduced to prevent health problems. Older workers and workers with disabilities can be used as the sources of required skills. Such unutilized workers need to be recruited and well-managed to ensure that their skills are retained [35]. In order to improve the well-being of older workers, the authors in [17] considered the influence of organizational factors, whereas those in [36] examined psychosocial factors at workplace. Unfulfilled prospects for work in old age influenced the prosperity of older workers [41]. Therefore, it is necessary to perform workplace health promotion activities [7].

Promote the lifelong learning. The growth of the aging labour force and emerging technologies change the work environment, generating a need to train older workers to improve their skills. Older workers gain benefits when well-designed training approaches are used. Therefore, the authors in [38] studied the training requirements and work experience, as well as the perception of ideal job features. To encourage technology adoption in the work environment, there is a need to understand how workers study software tools and complete assignments [8]. Therefore, further research should concentrate on developing safer work practices and supporting worker's productivity and professional longevity [37].

Encourage the late retirement. In order to achieve more successful inclusion of older people into labour market, there is a need for more comprehensive policies and harmonized all-age legislation. This is indicated by the fact that the overall decrease in the share of individuals in pension and disability programs is caused by changes in regulations [43]. In this regard, the authors in [20] studied the factors that affect the aging labour force and the range of current policies that suggest the possible opportunities for innovation. The implications for older workers are related to lifespan earnings, job retention, retirement savings, the possibility of changing jobs, or employment assurance $[13,44]$. Increasing the pension age should not exacerbate social and health disproportion in the older workers [40]. This is important since many older workers report unequal options to take advantage of solutions for supporting the balance between work and private life [42].

The abovementioned policy implications may be useful from policy making perspective. They could lead to the creation of framework that targets government, the non-governmental sector, private sectors and other stakeholders. However, the creation of such policy framework should take into account many other contributing factors [28] that can be the subject for future research activities. Furthermore, a future research agenda should consider the concept of ageing at work at national level and intensify collaboration at international level. Nevertheless, the following recommendations for governments and other stakeholders can be drawn from this research study:

1. Encourage incentives to extend the working ability in old age;

2. Eliminate age-based discrimination at work along with promotion of gender equality;

3. Invest in education, lifelong learning, health and well-being while increasing the productivity;

4. Improve the working conditions to increase the safety at work and health of workers;

5. Support late retirement along with the increase of life expectancy;

6. Reduce the use of early retirement if workers' health and work ability are satisfactory.

\subsection{Study Strengths and Limitations}

This study provides a systematic review of articles related to the aging labour force in terms of recent trends and future directions. Additionally, it identifies and evaluates the motivations that drive research on the aging labour force and potential solutions that address the issues related to the aging at work. Sustainable growth and age-based discrimination are recognized as the main motivations to perform the research activities in the given context. On the other hand, policies that stimulate life-long learning are identified as a potential solution for the aging labour force. The additional value 
of this study lies in its identification of policy implications and recommendations for governments and other stakeholders.

Furthermore, along with this paper, we also provide a Supplementary Materials of all identified relevant articles that can be filtered in terms of different fields to recognize articles for further analysis in a particular subfield. This initial search for a systematic review design may provide useful results on the relevance, practicability, and time needed to carry out a systematic review.

Despite the valuable insights in this study, it suffers from several limitations as well. First, this study took into consideration only three digital libraries, so some relevant articles could be unintentionally omitted from the study because of the specificity of the search strings and the fact that we have not taken into account the non-indexed publishers. However, the size of the searched digital libraries is sufficient, so the obtained results are suitable for the purpose of the study. Additionally, the articles obtained for this study are the results of a search query sent to different search engines with different retrieving and formatting rules from those that are used in the considered libraries. However, we are convinced that the specificities of the publishers' search engines had no influence on the findings of this study, taking into the account the number of analyzed articles.

Finally, the articles are categorized to provide the quantitative results that show the recent trends and future directions of aging at work, whereas the qualitative results are manually covered to a limited extent to describe the motivation issues and solutions for the aging labour force.

\section{Conclusions}

The aging of the population raises many issues and provides many opportunities. It intensifies the requirement for long-term care, healthcare, and a better-skilled workforce, and increases the demand for age-friendly environments. On the other hand, it enables the contributions of older people to their family, local community, or broader society.

In order to review articles related to the ageing at work in terms of recent trends and future directions, we performed a scoping literature review using an NLP-based framework to automate some of the steps in the PRISMA methodology and quickly identify potentially relevant articles. As a result, starting from over 70 thousand potentially relevant articles, we analyzed in detail about 70 of the most relevant approaches and discussed 24 of them.

We identified that the most prominent works suggest policies and practices that support life-long learning, a workforce that comprises both younger and older workers, and gradual retirement. Approaches like these could be the best response to the globalization issues, reduction of workforce, maintenance of financial independence of the aging workforce, and other social benefits.

Future work could be focused on standardizing approaches to this problem across different countries, supported by different policymakers. The goal should not be to end up with the same approaches in different environments, as this would hardly encompass all cultural, sociological, and economic factors. Instead, we believe that systematically documented and well-thought-out approaches will facilitate the measurement of the results and analysis of causality when investigating benefits and drawbacks.

Supplementary Materials: Supplementary Materials can be found at http:/ /www.mdpi.com/1660-4601/17/20/ 7659/s1. Table S1: Supplementary list-Data.

Author Contributions: Conceptualization: J.B.H., S.B., V.T., methodology: J.B.H., S.B., V.T., E.Z., software: P.L., E.Z., validation: F.J.M., P.M., O.K., N.M.G., interpretation: F.J.M., P.M., exploration: J.B.H., F.M., S.B., P.L., E.Z., P.M., O.K., N.M.G., V.T., writing-original draft preparation: J.B.H., S.B., P.L., E.Z., V.T., writing一review: J.B.H., F.M., S.B., P.L., E.Z., P.M., O.K., I.C., N.M.G., V.T., and editing: J.B.H., F.J.M., S.B., P.L., E.Z., P.M., O.K., I.C., N.M.G., V.T. All authors have read and approved to the final version of the manuscript for publication.

Funding: V.T., E.Z., I.C. and P.L. acknowledge the support of Faculty of Computer Science and Engineering, Ss. Cyril and Methodius University in Skopje, North Macedonia. In addition, this manuscript is funded by FCT/MEC through portuguese national funds and when applicable co-funded by FEDER-PT2020 partnership agreement under the project UIDB/EEA/50008/2020 (Este trabalho é financiado pela FCT/MEC através de fundos nacionais e quando aplicável cofinanciado pelo FEDER, no âmbito do Acordo de Parceria PT2020 no âmbito do projeto UIDB/EEA/50008/2020). This manuscript is based upon work from COST Action IC1303-AAPELE-Architectures, 
Algorithms, and Protocols for Enhanced Living Environments and COST Action CA16226-SHELD-ON-Indoor living space improvement: Smart Habitat for the Elderly, supported by COST (European Cooperation in Science and Technology). COST is a funding agency for research and innovation networks. Our actions help connect research initiatives across Europe and enable scientists to grow their ideas by sharing them with their peers. This boosts their research, career and innovation. More information in www.cost.eu. Based on CA16226 project, LTC18035 INTER COST was proposed for national funding support of COST ACTION Framework by MEYS, Czech Republic. This work was also supported in part by the project (2020/2206), Grant Agency of Excellence, University of Hradec Kralove, Faculty of Informatics and Management, Czech Republic.

Conflicts of Interest: The authors declare no conflict of interest. The founders had no role in the design of the study; in the collection, analyses, or interpretation of data; in the writing of the manuscript; or in the decision to publish the results.

\section{References}

1. World Population Ageing 2019. Available online: https://www.un.org/development/desa/pd/sites/www. un.org.development.desa.pd/files / files/documents/2020/Jan/un_2019_worldpopulationageing_report. pdf (accessed on 20 May 2020).

2. Ageing. Available online: https://www.un.org/en/sections/issues-depth/ageing/index.html (accessed on 20 May 2020).

3. Moreira, A.; Whelan, B.; Zaidi, A. The Demand for Older Workers. In Ageing, Health and Pensions in Europe: An Economic and Social Policy Perspective; Palgrave Macmillan: London, UK, 2010; pp. 247-281. [CrossRef]

4. Potočnik, K. Healthy Ageing and Well-Being at Work. In The Palgrave Handbook of Age Diversity and Work; Palgrave Macmillan: London, UK, 2017. [CrossRef]

5. Ageing Europe: Looking at the Lives of Older People in the EU. Available online: https: / / ec.europa.eu/eurostat/statistics-explained/index.php?title=Ageing_Europe_-_looking_at_the_ lives_of_older_people_in_the_EU (accessed on 9 October 2020).

6. Baraković, S.; Baraković Husić, J.; van Hoof, J.; Krejcar, O.; Maresova, P.; Akhtar, Z.; Melero, F.J. Quality of Life Framework for Personalised Ageing: A Systematic Review of ICT Solutions. Int. J. Environ. Res. Public Health 2020, 17, 2940. [CrossRef] [PubMed]

7. Poscia, A.; Moscato, U.; La Milia, D.I.; Milovanovic, S.; Stojanovic, J.; Borghini, A.; Collamati, A.; Ricciardi, W.; Magnavita, N. Workplace health promotion for older workers: A systematic literature review. BMC Health Serv. Res. 2016, 16. [CrossRef] [PubMed]

8. Vizer, L.M.; Hanson, V.L. Generations in the Workplace: An Exploratory Study with Administrative Assistants. In Universal Access in Human-Computer Interaction. Applications and Services; Stephanidis, C., Ed.; Springer: Berlin/Heidelberg, Germany, 2009; pp. 441-450.

9. EU-OSHA; Cedefop; Eurofound; EIGE. Joint Report on towards Age-Friendly Work in Europe: A Life-Course Perspective on Work and Ageing from EU Agencies; Publications Office of the European Union: Luxembourg, 2017.

10. Taylor, P.; McLoughlin, C.; Earl, C. Everyday discrimination in the Australian workplace: Assessing its prevalence and age and gender differences. Australas. J. Ageing 2019, 37, 245-251. [CrossRef] [PubMed]

11. Bergeron, C.D.; Friedman, D.B.; Messias, D.K.H.; Spencer, S.M.; Miller, S.C. Older women's responses and decisions after a fall: The work of getting "back to normal”. Health Care Women Int. 2016, 37, 1342-1356. [CrossRef] [PubMed]

12. Peterson, C.L.; Murphy, G. Transition from the labor market: Older workers and retirement. Int. J. Health Serv. 2010, 40, 609-627. [CrossRef] [PubMed]

13. Gabriele, R.; Tundis, E.; Zaninotto, E. Ageing workforce and productivity: The unintended effects of retirement regulation in Italy. Econ. Politica 2018, 35, 163-182. [CrossRef]

14. Blaine, E.B.; McClure Brenchley, K.J. Understanding the Psychology of Diversity; Sage Publications: Thousand Oaks, CA, USA, 2013.

15. Sustainable Work. Available online: https://www.eurofound.europa.eu/topic/sustainable-work (accessed on 21 May 2020).

16. Moen, P.; Kojola, E.; Schaefers, K. Organizational Change Around an Older Workforce. Gerontologist 2017, 57, 847-856. [CrossRef]

17. Palermo, J.; Fuller-Tyszkiewicz, M.; Walker, A.; Appannah, A. Primary-and secondary-level organizational predictors of work ability. J. Occup. Health Psychol. 2013, 18, 220-229. [CrossRef] 
18. Arensberg, M.B. Population aging: Opportunity for business expansion, an invitational paper presented at the Asia-Pacific Economic Cooperation (APEC) International Workshop on Adaptation. J. Health Popul. Nutr. 2018, 37. [CrossRef]

19. Pransky, G.S.; Fassier, J.B.; Besen, E.; Blanck, P.; Ekberg, K.; Feuerstein, M.; Munir, F. Sustaining Work Participation Across the Life Course. J. Occup. Rehabil. 2016, 26, 465-479. [CrossRef]

20. Barusch, A.S.; Luptak, M.; Hurtado, M. Supporting the Labor Force Participation of Older Adults: An International Survey of Policy Options. J. Gerontol. Soc. Work 2009, 52, 584-599. [CrossRef] [PubMed]

21. Navarro Ortega, S.A.; Munuera Gómez, M.P. Accessibility and New Technology MOOC- Disability and Active Aging: Technological Support. In Proceedings of the Future Technologies Conference (FTC) 2018; Advances in Intelligent Systems and Computing; Springer: Cham, Switzerland, 2018. [CrossRef]

22. Wainwright, T.; Kibler, E.; Kautonen, T.; Blackburn, R. One Size Does Not Fit All: Uncovering Older Entrepreneur Diversity through Motivations, Emotions and Mentoring Needs. In Entrepreneurship, Self-Employment and Retirement; Palgrave Macmillan: London, UK, 2015. [CrossRef]

23. Derek, R. Aging and work: An overview. In Occupational Medicine; Oxford: London, UK, 2011. [CrossRef]

24. Beck, V. Employers' use of older workers in the recession. Empl. Relat. 2013, 35, 257-271. [CrossRef]

25. Moher, D.; Liberati, A.; Tetzlaff, J.; Altman, D.G.; Group, P. Preferred reporting items for systematic reviews and meta-analyses: The PRISMA statement. PLoS Med. 2009, 6, e1000097. [CrossRef] [PubMed]

26. Zdravevski, E.; Lameski, P.; Trajkovik, V.; Chorbev, I.; Goleva, R.; Pombo, N.; Garcia, N.M. Automation in systematic, scoping and rapid reviews by an NLP toolkit: A case study in enhanced living environments. In Enhanced Living Environments; Springer: Cham, Switzerland, 2019; pp. 1-18.

27. Loncar-Turukalo, T.; Zdravevski, E.; Machado da Silva, J.; Chouvarda, I.; Trajkovik, V. Literature on Wearable Technology for Connected Health: Scoping Review of Research Trends, Advances, and Barriers. J. Med. Internet Res. 2019, 21, e14017. [CrossRef]

28. Field, J.; Burke, R.J.; Cooper, C.L. The SAGE Handbook of Aging, Work and Society; Sage Publications: Thousand Oaks, CA, USA, 2013.

29. Clark, R.L.; Ogawa, N.; Kondo, M.; Matsukura, R. Population decline, labor force stability, and the future of the Japanese economy. Eur. J. Popul.n/Rev. Eur. Démogr. 2010, 26, 207-227. [CrossRef]

30. Reinhardt, J.D.; Wahrendorf, M.; Siegrist, J. Socioeconomic position, psychosocial work environment and disability in an ageing workforce: A longitudinal analysis of SHARE data from 11 European countries. Occup. Environ. Med. 2012, 70. [CrossRef]

31. Cheung, F.; Wu, A.M.S. An investigation of predictors of successful aging in the workplace among Hong Kong Chinese older workers. Int. Psychogeriatr. 2012, 24, 449-464. [CrossRef]

32. Thorsen, S.V.; Jensen, P.H.; Bjørner, J.B. Psychosocial work environment and retirement age: A prospective study of 1876 senior employees. Int. Arch. Occup. Environ. Health 2016, 89, 891-900. [CrossRef]

33. Hui-Chuan, H. Age Differences in Work Stress, Exhaustion, Well-Being, and Related Factors From an Ecological Perspective. Int. J. Environ. Res. Public Health 2018, 16, 50. [CrossRef]

34. Park, J.; Kim, S.G.; Park, J.S.; Han, B.; Kim, K.B.; Kim, Y. Hazards and health problems in occupations dominated by aged workers in South Korea. Ann. Occup. Environ. Med. 2017, 29, 27. [CrossRef] [PubMed]

35. Bjelland, M.J.; Bruyere, S.M.; Von Schrader, S.; Houtenville, A.J.; Ruiz-Quintanilla, A.; Webber, D.A. Age and disability employment discrimination: Occupational rehabilitation implications. J. Occup. Rehabil. 2010, 20, 456-471. [CrossRef] [PubMed]

36. Thorsen, S.; Rugulies, R.; Løngaard, K.; Borg, V.; Thielen, K.; Bjorner, J.B. The association between psychosocial work environment, attitudes towards older workers (ageism) and planned retirement. Int. Arch. Occup. Environ. Health 2011, 85, 437-445. [CrossRef] [PubMed]

37. Tonelli, S.; Culp, K.; Donham, K. Work-related musculoskeletal disorders in senior farmers: Safety and health considerations. Workplace Health Saf. 2014, 62, 333-341. [CrossRef] [PubMed]

38. Lee, C.C.; Czaja, S.J.; Sharit, J. Training older workers for technology-based employment. Educ. Gerontol. 2009, 35, 15-31. [CrossRef] [PubMed]

39. Castro, C.M.S.; Lima-Costa, M.F.; César, C.C.; Neves, J.A.B.; Andrade, F.B.D.; Souza, J.P.R.B.; Sampaio, R.F. Life course and work ability among older adults: ELSI-Brazil. Rev. Saude Publica 2018. [CrossRef]

40. Maimaris, W.; Hogan, H.; Lock, K. The Impact of Working Beyond Traditional Retirement Ages on Mental Health: Implications for Public Health and Welfare Policy. Public Health Rev. 2010, 32, 532-548. [CrossRef] 
41. Clarke, P.; Marshall, V.W.; Weir, D. Unexpected Retirement from Full Time Work after Age 62: Consequences for Life Satisfaction in older Americans. Eur. J. Ageing 2013, 9, 207-219. [CrossRef]

42. Richert-Kaźmierska, A.; Stankiewicz, K. Work-life balance: Does age matter? Work 2016, 55, 679-688. [CrossRef]

43. Nilsson, K.; Östergren, P.O.; Kadefors, R.; Albin, M. Has the participation of older employees in the workforce increased? Study of the total Swedish population regarding exit from working life. Scand. J. Public Health 2016, 44, 506-516. [CrossRef] [PubMed]

44. Hyun, J.; Sliwinski, M.J.; Almeida, D.M.; Smyth, J.M.; Scott, S.B. The moderating effects of aging and cognitive abilities on the association between work stress and negative affect. Aging Ment. Health 2017, 22, 611-618. [CrossRef]

Publisher's Note: MDPI stays neutral with regard to jurisdictional claims in published maps and institutional affiliations.

(C) 2020 by the authors. Licensee MDPI, Basel, Switzerland. This article is an open access article distributed under the terms and conditions of the Creative Commons Attribution (CC BY) license (http:/ / creativecommons.org/licenses/by/4.0/). 